日臨外会誌 $63(10), 2525-2528,2002$

症例

膵胆管合流異常症にみられた総胆管コレステローシスの１例 国保中央病院外科

赤堀宇広大山孝雄安川十郎吉川高志

総胆管コレステローシスは非常に稀で術前診断が困難な疾患である．われわれは術前

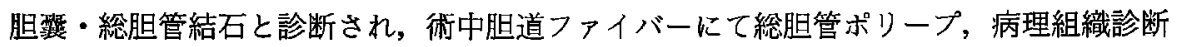
にてポリープ型コレステローシスと診断された 1 例を経験したので, 若干の文献的考察 を加え報告した. 症例好48歳, 女性. 嘔気, 心裔部痛を主訴に当院内科受診. 軽度の肝 機能異常を認め, 腹部超音波検查にて胆蕗結石, ERCP にて膵胆管合流異常症, 胆琵管 低位合流，胆琵総胆管結石と診断され，手術目的に当科紹介となった，手術は，胆琹摘 出術, 総胆管切開術を施行した。総胆管内に結石を認めず, 下部胆管に多数の黄白色の ポリープ様病変を認めた，総胆管コレステローシスは，ほとんどが下部胆管の腫煌性病 変と診断され手術を施行されるが, 病的意義は少ないとされており, 胆道鏡での確診が 容易なため，今後経内視鏡的胆道ファイバーの普及により，不要な手術を避けられるも のと考光られた。

索引用語：総䏣管，コレステローシス

はじめに

総胆管コレステローシスは，胆露のそれに比して， 非常に稀な疾患である.1958年に最初に Fock ${ }^{13}$ が報告 しているが，その後，本邦においては自験例を含め 25 例の報告を認めるにすぎな(2244)6122．また，各種画像 診断が進歩した今日に招いても術前に診断することが 困難な疾患である．今回著者らは，術前検查にて総胆 管結石症と診断され，術中胆道ファイパーで総胆管ポ リープ, 病理組織診断にてポリープ型コレステローシ スと鲴断された 1 例を経験したので若干の文献的考察 を加えて報告する。

\section{症例}

患者：48嵅，女性.

主訴：嘔気，心䆟部痛.

家族歴：母泹裂結石症，父治糖尿病.

既往歴：11歳時, 虫垂炎にて虫垂切除術施行。

現病歴: 平成 12 年 8 月初旬より, 心窩部痛が存在し, 当院内科受䛦. 胆禁結石を指摘される.11月 7 日に精 査のため $\mathrm{ERCP}$ 施行され，総胆管結石症を指摘される

2001年10月19日受付 2002年 7 月 24 日採用 〈所属施設住所〉

₹ 636-0302 奈良県磯城郡田原本町宮古404- 1
も膵胆管合流異常症が存在したため, 内視鏡的乳頭切 開術などの内視鏡的処置不可と判断され手術目的に当 科紹介入院となる。

入院時現症：身長 $151 \mathrm{~cm}$, 体重 $56 \mathrm{~kg}$. 眼瞼眼球結膜 に貧血黄染を認めず．表在リンパ節は触知せず。胸部 打恥診上異常なく, 腹部は平坦靯で肝脾触知しなかっ た.

入院時検查所見 : 生化学検查で GOT $36 \mathrm{IU} / 1, \mathrm{GPT}$ $61 \mathrm{IU} / 1, \gamma$-GTP $24 \mathrm{IU} / 1$ と肝胆道系酵素の軽度上昇を 認める以外，異常を認めなかった。 なお，血中の CEA 0.5ng $/ \mathrm{ml}$, CA19-9 19U/mlであった（表 1 ).

超音波検査：胆鸾頸部に計11 mm の音響陰影を伴う strong エコーを認め, 胆石症と診断した。な圾, 総胆 管内に結石の存在を疑わせる high echoic mass を認 めず，肝内胆管，総胆管に明らかな㹡張を認めなかっ た(図 1$)$.

ERCP 検查：総胆管下部に約 $5 \mathrm{~mm}$ 大の陰影欠損 像, 胆㱥内に 2 個の陰影欠損像を認めたため, 胆琵結 石症および総胆管結石症と診断した。 また，胆郦管低 位合流抒よび膵胆管合流異常症を認めたため, 内視鏡 的乳頭切開術などの内視鏡的処置不可と判断した（図 2 ).

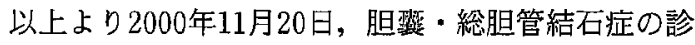


表 1 入院時一般検査

\begin{tabular}{|c|c|c|c|c|}
\hline \multicolumn{3}{|l|}{ 末血検查 } & \multicolumn{2}{|c|}{ 生化学検查 } \\
\hline $\mathrm{RBC}$ & $457 \times 10^{4}$ & $/ \mathrm{mm}^{3}$ & T-Bil & $0.8 \mathrm{IU} / 1$ \\
\hline $\mathrm{Hb}$ & 13.8 & $\mathrm{~g} / \mathrm{dl}$ & GOT & $36 \mathrm{IU} / 1 \uparrow$ \\
\hline $\mathrm{Ht}$ & 41.0 & $\%$ & GPT & $61 \mathrm{IU} / 1 \mathrm{~T}$ \\
\hline WBC & 4.460 & $/ \mathrm{mm}^{3}$ & $\mathrm{LDH}$ & $345 \mathrm{IU} / 1$ \\
\hline \multirow[t]{2}{*}{ Plt } & \multirow{2}{*}{\multicolumn{2}{|c|}{$27.0 \times 104 / \mathrm{mm}^{3}$}} & AMY & $60 \mathrm{IU} / 1$ \\
\hline & & & BUN & $11.3 \mathrm{mg} / \mathrm{dl}$ \\
\hline 尿榆査 & & & Cre & $0.5 \mathrm{mg} / \mathrm{dl}$ \\
\hline $\mathrm{pH}$ & 6.0 & & $\mathrm{TP}$ & $8.1 \mathrm{~g} / \mathrm{dl}$ \\
\hline 糖 & $(-)$ & & ALB & $5.1 \mathrm{~g} / \mathrm{dl}$ \\
\hline 蛋白 & $(+-)$ & & $\boldsymbol{y}$-GTP & $24 \mathrm{IU} / 1 \boldsymbol{\top}$ \\
\hline 潜血 & $(-)$ & & $\mathrm{CPK}$ & $104 \mathrm{mg} / \mathrm{dl}$ \\
\hline \multicolumn{3}{|l|}{ 腫瑒マーカー } & CRP & $0.2 \mathrm{mg} / \mathrm{dl}$ \\
\hline CEA & 0.5 & $\mathrm{ng} / \mathrm{ml}$ & $\mathrm{Na}$ & $144 \mathrm{mEq} / \mathrm{l}$ \\
\hline \multirow[t]{2}{*}{ CA19-9 } & 19 & $\mathrm{U} / \mathrm{ml}$ & $\mathrm{K}$ & $4.0 \mathrm{mEq} / 1$ \\
\hline & & & $\mathrm{Cl}$ & $103 \mathrm{mEq} / \mathrm{l}$ \\
\hline
\end{tabular}

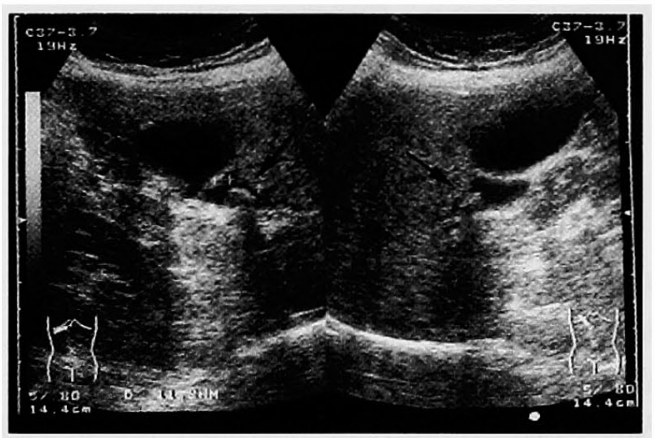

図 1 腹部超音波検査：胆葚頸部に計 $11 \mathrm{~mm} の$ 陰影 欠損を伴う strong エコーを認める.

断で手術を施行した。

手術所見：上腹部正中切開にて開腹. 胆袈摘出後, 総胆管を切開し術中胆道鏡検查を施行したところ総胆 管下部に直径約 $1 \mathrm{~mm}$ の黄白色調のポリープ様病変が 多数認められた(図 3 )。総胆管ポリープと診断し病理 学的検索のため, 一部を採取し T-tube を挿入し手術 を終了した。な报, 胆汁中の amylase 值は, 35,750IU/ 1 と高値を示し, また, 胆汁中の CEA, CA19-9 は, そ れぞれ $11.8 \mathrm{ng} / \mathrm{ml}, 10,000 \mathrm{U} / \mathrm{ml}$ 以上であった。

切除標本：胆罴内に 3 個の黑色石を認めた。 また胆 整粘膜は軽度の炎症所見を示し, ほぼ全般にビロード 状のコレステリンの沈着を認めた。

病理組織学的所見：胆整抢よび採取した病変のどち らにおいても粘膜上皮細胞直下にコレステリンを多量 に含む，明るく腫大した foam cell の集簇を認め、コ

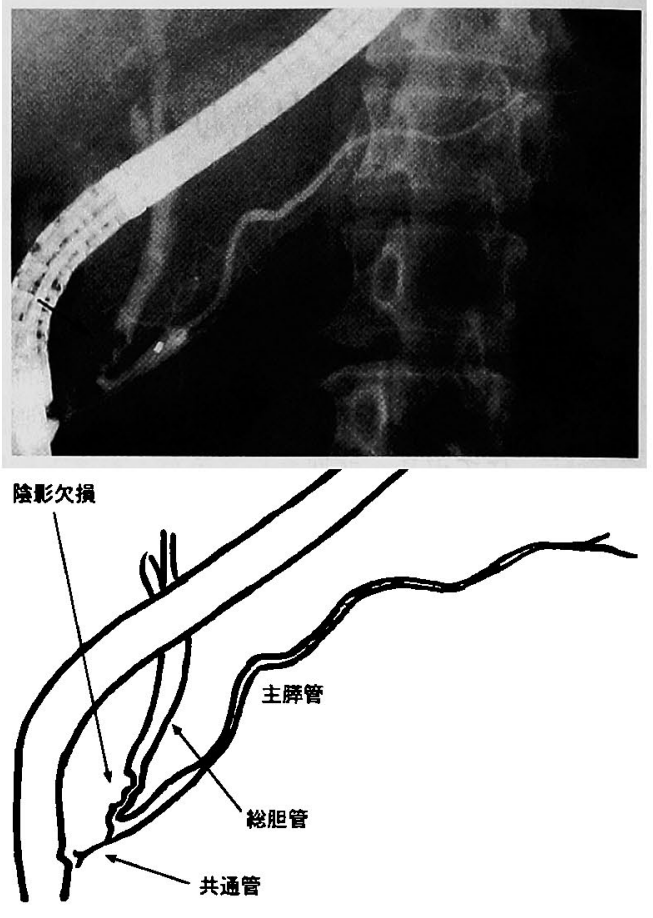

目 2 ERCP 検査：a )総胆管は拡張を認めず，総胆 管末端に約 $5 \mathrm{~mm}$ 大の陰影欠損像と膵胆管合流異 常症を認める. b ) シェーマ.
レステローシスと診断された（図4）.

術後経過：術後 Tチューブ造影では, 総胆管下部に 術前と同様の陰影欠損像を認める他, 総胆管の㹡張, 狭窄など認めなかった。術後の胆道鏡検査では, 術中 と同様に総胆管下部に黄白色の多数のポリープを認め る以外, 異常を認めなかった，術後経過良好であり， 術後32日目に退院となった。退院後, 肝機能異常など 認めず，外来通院中である。

\section{考察}

胆䪄に扔けるコレステローシスに関しては，日常臨

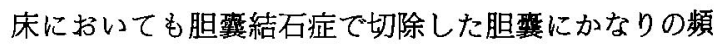
度で認められるように，全しいものではなく，1857年 の $\mathrm{Virchow}^{3}$ の報告以来, 多数の報告例がある.その一 方で，総胆管のコレステローシスは，1958年に Fock ${ }^{1)}$ が最初に報告しているが，非常に稀な疾患であり，本 邦では, 1985年の岡信ら4の報告が最初で, 以降検索し えた限りにおいて自験例を含めて25例の報告を数える に過ぎない。

胆蛒のコレステローシスは病理組織学的に, 粘膜上 


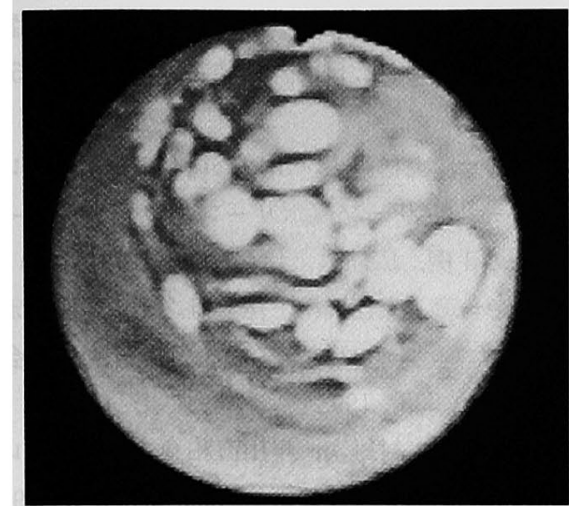

図 3 術中胆道鏡検査：総胆管末端に直径約 $1 \mathrm{~mm}$ の黄白色調のポリープ様病変が多数 認められた。

皮で胆汁中のコレステロールが吸収され, ester 化され たものを貪食した macrophageがいわゆる foam cell の形となり粘膜固有層に集簇し，粘膜に突出した状態 を示すとされている5 . 総胆管のコレステローシスの 病理組織も類似の組織像を示し，その成因は胆露のそ れと同様であると考えられている5 . 本症例の組織像 においても胆繁，総胆管の両者の粘膜上皮細胞直下に コレステリンを多量に含む抱体をもち，明るく腫大し た foam cell の集簇を認めている. 総胆管内での発生 部位が自験例を含め25例中24例総胆管下部乳頭部付近 であることより，有本ら ${ }^{2)} は$ 胆汁組成や粘膜の性質が 胆䧶に近い状態にあるのではないかと推察している が,いずれにせよ，胆露内と総胆管内では胆汁の性状， 動態などが異なっていると考えられ，このことが，頻 度の違いとして現れてきているものと考えられる。今 後の検討を待ちたい.

本症は径 $1 \mathrm{~mm}$ 前後の集簇した黄白色のポリープ状 の特徴ある形態7を示し，肉眼的には比較的容易に診 断可能であると考えられる。しかしながら，発生部位 が総胆管内のため，現実には肉眼的な画像所見を得る ことは難しく，各種画像診断が進歩した今日において も術前䛦断が困難な疾患である。本邦報告例において も，胆管癌，膵癌などの悪性疾患や肝内結石症などの 良性疾患に対する衍前検查で，経皮経肝胆道鏡検查を 施行された際に偶然肉眼的に発見されたもの以外は， 術前総胆管結石症あるいは総胆管内の腫瘍性病変と診 断され，術中胆道鏡検查にて確認される形となり，手 術中に診断されている。本症例に扔いても総胆管結石

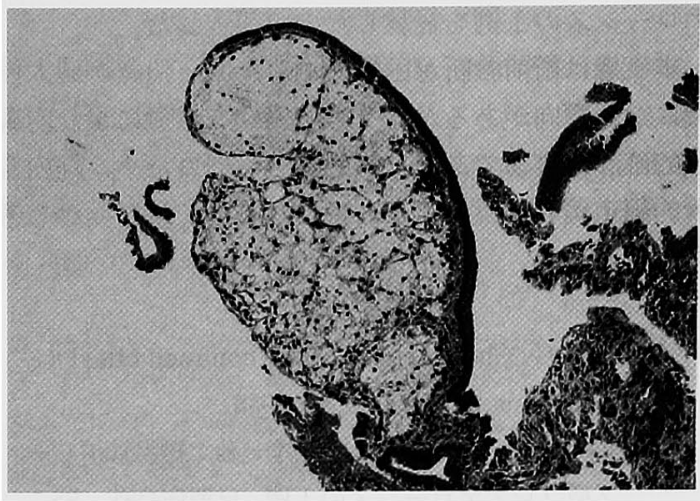

図4 病理組織所見：摘出した病変の粘膜上皮細胞直下 にコレステリンを多量に含む抱体をもち，明るく腫大 した foam cell の集簇を認めた（H. E. $\times 200 ）$.

の診断のもと, 総胆管を切開し, 術中胆道鏡で確認さ れた。

総䏣管コレステロールポリープが，悪性化した，あ るいは狭窄症状や結石形成への関与を示したなどの報 告は, 小野寺ら ${ }^{8}$ の 6 年間のフォローアップの報告も 含め, 本邦における報告例はなく, 病的意義は認めに くい.にもかかわらず, 発生好発部位が, 乳頭部付近 という特殊な場所にあるため, 総胆管部分切除, 胆管 空腸吻合あるいは，膵頭十二指腸切除術を施行された 例があり過大侵襲といわざるを得ない。 また，可及的 ポリープ切除術などの手術も不要であると考えられ る.さらには, 自験例も含めて多数の症例で, 総胆管 を切開し衍中胆道鏡施行することにより初めてコレス テローシスと診断されているが, 病的意義の面から考 えると過大侵襲といえる.ただ, 神谷ら”の15例の報告 の中に, 7 例の先天性胆管拡張症の症例 ${ }^{201}$ が含まれて おり，詳細は不明で推測の域を出ないが，膵液の何ら かの関与の可能性に言及している. 本症例も膵胆管合 流異常症を合併しており，膵液の化学的あるいは機械 的刺激が何らかの形で本疾患の発生に関与する可能性 が残されている。また，コレステローシスそのものは 基本的に病的意義が少ないと思われるが，本症例のよ うに合流異常が存在する場合, 胆管癌発生の危険もあ り, ある程度の頻度で外来観察が必要であると思われ る.

以上のことより，今後は経内視鏡的胆道鏡など新し い検索法の普及, 開発および病因の解明が期待される.

\section{結語}

今回われわれは比較的稀な総胆管ポリープ型コレス 
テローシスの1例を経験したので報告した。

本疾患㯈術前診断が困難であるため，治療が過大侵

襲になる傾向があるが，その特徵的な形態により内視 鏡的確診は容易であり, 病的意義も低いため, 経内視 鏡的胆道鏡の普及により改善されるのではないかと考 えられた。

\section{文 献}

1) Fock $G$ : Cholesterosis of the conmon bile duct. Acta Chir Scand 116: 33, 1958

2) 有本裕一, 山崎 修, 川井秀一他：総胆管ポリー プ型コレステローシスの1例. 日消病会誌 95： 348-352, 1998

3) Virchow $R$ : Uber das Epital der Gallenblase und uber einen intermediaren Stoffwechsel des Fettes. Virchow Arch Path Anat $11: 574,1857$

4) 岡信孝治, 大西長久, 富岡憲明: 総胆管多発ポリ ープ型コレステローシスの1例. 胆と萃 6 ： $1427-1432,1985$

5）為末紀元, 江口季夫, 志村秀彦: 特殊病態と治療 指針一Cholesterosis一, 肝 - 胆・膵 $7: 1003$ 1007,1983
6）徳村広実，清水文人，手塚文明：総胆管コレステ ローシスの2 例. 日消外会誌 $24: 2046-2050$, 1991

7）向井俊一,上村㨁夹，山口修司他：総胆管コレス テロールポリープ（ポリープ型コレステローシ ス）の1例. 広島医 $43: 1216-1219,1990$

8）小野寺一㢁，大江成博，澤 雅之他：総胆管ポリ 一プ型コレステローシスのI例. 日臨外医会誌 $54: 532-536,1993$

9）神谷順一，二村雄次，早川直和他：総胆管コレス テローシスの検討. 日消病会誌 $83: 189-195$, 1986

10）神谷順一，二村雄次，早川直和他：総胆管コレス テローシスを合併した先天性胆管拡張症の 1 例. 日消病会誌 $19: 1782-1785,1986$

11) Ikoma $A$, Ueno $T$, Tanaka $K$, et al: Cholesterol polyp of the common bile duct. Am J Gastroenterol 90 : 1534-1535, 1995

12) Kin $Y$, Nimura $Y$, Kamiya J, et al : Cholesterosis in bile duct carsinoma. Gastrointest Endosc $40: 92-93,1994$

\title{
A CASE OF CHOLESTEROSIS OF THE COMMON BILE DUCT
}

\author{
Takahiro AKAHORI, Takao OHYAMA, Juro YASUKAWA and Takashi YOSHIKAWA \\ National Insurance Union of Nara Central Hospital
}

Cholesterosis of the common bile duct is very rare and difficult to be diagnosed before operation. We report a case cholesterosis of the common bile duct that was definitely diagnosed pathologically after diagnosed as cholecystocholedocholithiasis before operation.

A 48-year-old woman was admitted to the hospital because of nausea and epigastralgia. Endoscopic cholangiography showed anomalous arrangement of the pancreaticobilialy ductal system and cholecystocholedocholithiasis. So she underwent a cholecystectomy and a choledochotomy with a $T$-tube dranage. Intraoperative cholangioscopy revealed a yellowish-white multipolypoid lesion in the lower common bile duct. The polyp was diagnosed as cholesterosis histologically.

Cholesterosis of the common bile duct is diagnosed as tumor like lesion and subjected to surgical operation in most cases. But this disease has been thought less significant clinically, and it is easily diagnosed by cholangioscopy. We think that oversurgery may be avoidable with a spread of oral cholangioscopy. 